Bisset, K. A. (1953). J. gen. Microbiol. 8, 50-57.

\title{
Do Bacteria have Mitotic Spindles, Fusion Tubes and Mitochondria?
}

\author{
By K. A. BISSET \\ Department of Bacteriology, University of Birmingham
}

\begin{abstract}
SUMMARY: Cytological studies upon species of Bacillus, Bacterium and Mycobacterium have shown that recent claims to demonstrate true mitotic spindles, mitochondria and fusion tubes in these genera are based upon a misinterpretation of the basophilic growing points and septa commonly found in bacteria, and a misunderstanding of the multicellular structure of Bacillus and Mycobacterium.
\end{abstract}

I have often drawn attention to the errors of interpretation which may arise from failure to recognize that many bacteria are divided into numerous, small cells by cross-walls and septa (Bisset, 1948 $a, b, 1950,1951 a, 1952 a, b$ ). This is especially true of Bacillus and Mycobacterium. These observations are not new, and were clearly illustrated by Knaysi (1929, 1930), who also showed that these septa may appear as small granules on the periphery of the cell. In the present paper it will be shown that, in B. megaterium, these granules have been misinterpreted as the centrioles of mitotic spindles. Multicellularity in Bacillus was illustrated with great clarity by Robinow (1945), who stated: 'Transverse cell walls are very conspicuous in $\boldsymbol{B}$. megatherium....' The cross-walls were also very clearly demonstrated by Murray \& Robinow (1952) in partially disrupted preparations of B. cereus. Recently, Cassel (1951) succeeded in demonstrating simultaneously the cell walls and nuclei in $B$. megaterium and in other species of Bacillus, showing once more that these bacilli contain four short cells, each with a pair of nuclear bodies typical of vegetative eubacteria (Robinow, 1945; Bisset, 1950).

Despite this evidence of the cytological structure of $B$. megaterium, this organism has recently been described by DeLamater \& Mudd (1951), as 'a multinucleate cell', the nuclei of which undergo 'a true, mitotic process'. 'This interpretation is based upon the appearance of so-called 'centrioles' which, in my opinion, are artefacts derived from the cross-walls and septa. This material was also published simultaneously, with the same evidence, by DeLamater \& Hunter (1951) and DeLamater (1951 $a, b)$. In the last quoted paper it is also claimed that $B$. megaterium conjugates by means of 'fusion tubes'; this appears to be an interpretation of the bacilli of small diameter which are frequently found among chains of larger organisms. This paper, and a subsequent one (DeLamater, 1952) describe what are claimed to be mitotic figures in micrococci, and a further study of $B$. megaterium (DeLamater \& Hunter, 1952) claims to show similar appearances in germinating spores. Here again it is my contention that it is developing septa, in dividing cells, which are responsible for the appearances upon which DeLamater bases his interpretation. 
A septate structure was also postulated in Mycobacterium by Brieger \& Robinow (1947), and demonstrated by Bisset $(1949,1950)$ and Bisset \& Moore (1949). However, Mudd, Winterscheid, DeLamater \& Henderson (1951), apparently unaware of these studies, produced literary and microchemical observations which led them to suggest that the 'granules' of Mycobacterium are really mitochondria. These supposed mitochondria are, in my opinion, complete protoplasts (Bisset, 1949). In a subsequent study Mudd, Brodie, Winterscheid, Hartman, Beutner \& McLean (1951) claimed that the stainable areas at the growing tips and points of division of Bacterium coli are also mitochondria, and presented micrographs of $\boldsymbol{B}$. megaterium showing a row of large granules, corresponding to the basophilic elements of developing septa, which were again stated to be mitochondria.

The purpose of the present paper is to describe the cytological structures observed in B. megaterium, Bact. coli and certain Mycobacterium species, and to show that the descriptions of mitotic spindles, fusion tubes and mitochondria are based upon misinterpretations of the cytological structure of these bacteria, and on failure to recognize multicellularity where it occurs.

\section{MATERIALS AND METHODS}

Four strains of $\boldsymbol{B}$. megaterium and one of a Mycobacterium sp. were freshly isolated from soil and dust. One strain each of $\boldsymbol{M}$. tuberculosis, $\boldsymbol{M}$. lacticola and B. megaterium were from the National Collection of Type Cultures. One strain of Bact. coli was freshly isolated from faeces.

Cultures were grown aerobically at $37^{\circ}, B$. megaterium and Bact. coli on nutrient agar, the mycobacteria on Löwenstein's egg medium. Preparations of $\boldsymbol{B}$. megaterium were made after $4 \mathrm{hr}$. incubation, and before the beginning of sporulation. These were stained by the acid Giemsa and tannic acid violet techniques (Robinow, 1945; Bisset, 1950), by thionine instead of Giemsa, as recommended by DeLamater \& Mudd (1951), or by thionine + thionyl chloride. For the demonstration of basophilic septa, preparations were stained by Heidenhain's iron alum haematoxylin and were mordanted at room temperature for $12 \mathrm{hr}$.

Preparations were never permitted to dry at any stage, were unfixed, and sealed in water under a coverslip for examination, which was always conducted immediately. None of the photomicrographs in this paper is of a preparation more than 2-3 hr. old, except those which, for comparison, were dehydrated in freezing alcohol according to the method of DeLamater (1951 $a$ ). The considerable differences between fresh water-mounted material and preparations subjected to dehydration in this manner are commented upon later (cf. Pl. 1, figs. 1, 8 and 9). Gold-shadowed electron micrographs were made of some of the material.

Because of its lipid content Mycobacterium is difficult to stain with aqueous dyes. The best results were obtained by defatting (Bisset, 1949) before staining, although this method departed from the principle of keeping the material in water at all stages. These preparations, nevertheless, were always watermounted for examination. 


\section{RESULTS}

The cytology of Bacillus megaterium

When stained by tannic acid violet to demonstrate the cell walls $B$. megaterium was seen to be composed of a number of short cells, typically four to a bacillus, separated by cross-walls in various stages of formation. These cross-walls showed either as diffuse lines, presumably representing an incomplete formation of cell wall material, or as single, well-defined lines where the process was complete. The centre wall of a bacillus was frequently double, representing an incipient division ( $\mathrm{Pl}$. 1, fig. 1).

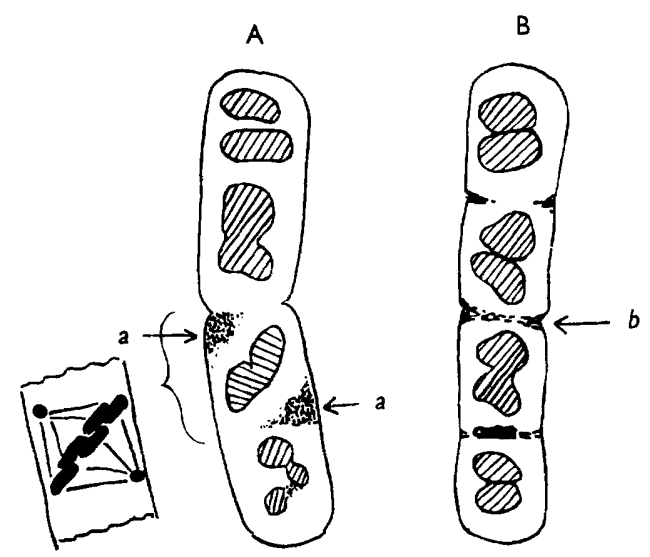

Fig. 1. A, drawing of photomicrograph of B. megaterium claimed by DeLamater (1951b, and several other papers) to show a 'metaphase spindle' (this interpretation is illustrated, inset, on the left). B, drawing of photomicrograph of B. megaterium from Pl. 1, fig. 4, in this paper. The 'centrioles' $(a)$ in DeLamater's figure correspond exactly to the stainable granules at the points of junction of the septa and cell wall $(b)$. Both preparations are stained by acid thionine, but whereas $B$ is mounted in water, $A$ has been subjected to the action of freezing alcohol.

The same organisms, briefly hydrolysed (exact time varying with strain) and then lightly stained by thionine, showed (Pl. 1, fig. 2) that the cell walls did not stain at all; the organism thus appeared very slender, the cross-walls were seen as unstained gaps, with strongly stained bars on each side. These bars are protoplasmic septa which precede and secrete the cell wall material of the cross-walls. In such preparations the nuclear material was not differentiated from the cytoplasm. Similar preparations, more strongly hydrolysed and stained, showed that these basophilic septa stained very deeply at their junctions with the cell wall, thus giving the appearance of discrete granules on the periphery or occasionally at other points on the septum (Pl. 1, fig. 3). These granules are elaimed by DeLamater \& Mudd (1951) to be the centrioles of mitotic spindles; they are also among the structures claimed by Mudd, Brodie et al. (1951) to be mitochondria.

In Pl. 1, figs. 4 and 5, B. megaterium is seen fully hydrolysed and stained by acid thionine. The paired nuclear bodies which almost fill the cells, and the basophilic elements of the cross-walls can clearly be seen. In Fig. 1, a drawing 
of one of these bacilli is compared with a drawing of a preparation which appears repeatedly (DeLamater, 1951 $a, b$; DeLamater \& Hunter, 1951; DeLamater \& Mudd, 1951) and which is claimed to show a mitotic spindle. The stainable elements of the cross-walls are seen very clearly in Pl. 1, figs. 6 and 7, stained by haematoxylin. In these cases the bacilli appear slender by comparison with Pl. 1, fig. 1, because the mature portions of the cell wall do not stain by these methods.

To study the effect of DeLamater's technique of dehydration in freezing alcohol, by comparison with unfixed fresh material mounted in water, a variety of stained preparations were subjected to this treatment, exactly as described by DeLamater (1951 a). Results are seen in Pl. 1, figs. 8 and 9, which show the effect of the freezing alcohol technique upon the cell wall preparations of $\boldsymbol{B}$. megaterium stained by tannic acid violet. In some bacilli the multicellular structures shows very clearly, but the organisms are much shrunken in length and distorted. This observation is in accordance with the findings of Møller \& Birch-Andersen (1951) on the effect of fixation methods upon bacteria.

\section{The cytology of Mycobacterium}

When mycobacteria are stained by acid Giemsa or by a variety of cytochemical methods including the Feulgen technique (see Bisset, 1949, 1950, for literature), a row of granules is seen (Pl. 2, fig. 10), corresponding to the cells into which the bacillus can be observed to be divided when stained by tannic acid violet (Pl. 2, figs. 11 and 12). The basophilic elements in the crosswalls can also be discerned to some extent in Pl. 2, fig. 10. These septa also tend to stain most strongly at points of junction with the cell wall proper (Pl. 2, figs. 11, 12 and 14).

This multicellularity was equally obvious in a filamentous acid-fast organism from the soil (Pl. 2, figs. 14, 15), and in some very short rods from a culture of $M$. lacticola (Pl. 2, fig. 13). Both were subdivided by cross-walls into almost coccal cells. In dried, heat-fixed preparations of Mycobacterium, e.g. routine smears stained by Ziehl-Neelsen's stain, the entire contents of these cells, including the putative nuclear bodies, shrink into discrete granules (Bisset, 1949, 1950). These appear to be the 'mitochondria' of Mudd, Winterscheid et al. (1951).

\section{The growing points of Bacterium coli}

Pl. 2, fig. 16, shows a preparation of Bact. coli, unhydrolysed and stained with dilute Giemsa. The stainable areas at the growing tips and at the points of division (Bergersen, 1952; Bisset, 1948 $a, 1951 b, 1952 b$ ) are clearly seen. These stain reasonably well with any basic dye, and their appearance is reinforced by the optical illusion of viewing the basophilic cell envelopes across a longer section at these points (Bisset, 1951 $a$, 1952b), a well-known phenomenon usually referred to as 'bipolar staining'. 'These organelles appear to be among those claimed as mitochondria by Mudd, Brodie et al. (1951) on the ground that they are centres of oxidation-reduction activity. Since they are the areas in which active growth of the cell is occurring, it is perhaps to be 
anticipated that they would show marked biochemical activity. Reducing activity at the tips of bacteria was recorded by Bielig, Kausche \& Haardick (1949). The identity of these basophilic areas with mitochondria is, in my opinion, most unlikely.

\section{'Fusion tubes' in Bacillus megaterium}

Cultures of $\boldsymbol{B}$. megaterium frequently exhibit marked variability of cell form. This was remarked upon by Rettger \& Gillespie (1935) who depicted very small cells in series with chains of normal bacilli, but clearly demarcated by cross-walls. Such cells and their cross-walls were often seen in tannic acid violet preparations, especially those of bacilli grown on blood agar. The electron micrographs (Pl. 3, figs. 17, 18) show such appearances. DeLamater $(\mathbf{1 9 5 1} b)$ interpreted these structures as fusion tubes. However, as they are not continuous internally, and as most frequently they are attached to larger bacilli only at one end, they appear incapable of performing any such function.

\section{DISCUSSION}

The evidence presented upon the cytology of B. megaterium and Mycobacterium allows little doubt that the basic assumption made by the authors criticized here, namely that these organisms are single, rod-shaped cells, is unjustifiable. They are shown to be subdivided by complex cross-walls, the existence of which invalidates the description by these authors of mitotic spindles, fusion tubes and mitochondria. These misinterpretations have arisen from uncritical reliance upon non-specific staining methods and the use of an unsuitable technique of dehydration.

Analysis of the photographic material presented by DeLamater and his collaborators provides ground for serious criticism. Comparison of the photomicrographs in the various papers published simultaneously by DeLamater, by DeLamater \& Mudd and by DeLamater \& Hunter shows that all but two of the plates claiming to illustrate metaphase nuclei in $B$. megaterium are taken from the same photomicrograph of the same cell, reproduced at different magnifications, and in one case inverted. An explanation of the resemblance of this cell to a metaphase spindle is given in Fig. 1. Approximately 400 nuclei, claimed to be at other stages of the mitotic cycle, are balanced by this exceedingly flimsy evidence of the most characteristic stage. In the cocci and germinating spores, the 'metaphase' would appear to be an interpretation of two nuclear bodies separated by a developing septum.

Measurement of the organisms illustrated by DeLamater \& Mudd (1951), which are printed at a magnification of $\times 4450$, gives a mean length in the reproduction of $27 \mathrm{~mm}$. for twelve bacilli which clearly show the typical number of four nuclear elements, and which are stated to be at 'interphase', 'prophase' and 'metaphase'; thus the mean length occupied by a single nuclear unit is $6.7 \mathrm{~mm}$. The mean length occupied by nuclei from six bacilli, stated to be in 'anaphase' and 'telophase' is also $6.7 \mathrm{~mm}$. Thus there is no correlation between the length of the nuclei and their supposed state of division, or the growth of the cells. 
The evidence of Mudd, Winterscheid et al. (1951), in support of their interpretations, consists in the demonstration of granules in bacteria, and the claim that their staining reactions prove these to be mitochondria. In the case of Mycobacterium, from two to six of these granules are shown in organisms of a configuration which, in the photomicrographs of the present paper, and in the figures of the other workers quoted, have up to six complete cells. It is thus apparent that each of these granules comprises the major portion of the protoplasm of a cell, and may be expected to react with a wide range of reagents, specific for cell components. The basophilic areas at the poles and points of division of Bact. coli, described as 'mitochondria' by Mudd, Brodie et al. (1951) represent the points of growth of the cells (Bergersen, 1952; Bisset, $1948 a, 1950,1951 b)$; their biochemical activity is known and is to be expected of such material (Bielig et al. 1949). The comparable areas in the multicellular B. megaterium are the basophilic elements in the incipient septa and cross-walls. The same structures appear thus to have been described as 'mitochondria' by Mudd in his collaboration with Brodie et al. (1951), and as 'centrioles' by DeLamater \& Mudd (1951). None of the evidence presented to support the suggestion that any of these structures are mitochondria is adequate to overcome the objection of their obvious functional morphology and complete lack of any resemblance to mitochondria in form and arrangement.

It is thus concluded that these claims to demonstrate mitotic spindles, fusion tubes and mitochondria in bacteria are invalid, and are founded upon inaccurate premises and inadequately controlled methods.

\section{REFERENCES}

Bergersen, F. J. (1952). Cytological changes induced in $E$. coli by chloramphenicol. Proc. Univ. Otago med. Sch. 30, 3.

Bielig, H. J., Kausche, G. A. \& Haardick, H. (1949). Ueber den Nachweis von Reduktionsorten in Bakterien. Z. Naturf. 46, 80.

Bisset, K. A. (1948a). The cytology of smooth and rough variation in bacteria. J. gen. Microbiol. 2, 83.

Bisset, K. A. (1948b). The cytology of Gram-positive cocci. J. gen. Microbiol. 2, 126.

BisseT, K. A. (1949). Observations on the cytology of corynebacteria and mycobacteria. J. gen. Microbiol. $3,93$.

Brsset, K. A. (1950). The Cytology and Life-History of Bacteria. Edinburgh: Livingstone.

Bisset, K. A. (1951 $a)$. The morphology and cytology of bacteria. Ann. Rev. Microbiol. 5, 1.

BIsset, K. A. $(1951 b)$. The development of surface structures in dividing bacteria. J. gen. Microbiol. 5, 155.

Bisser, K. A. (1952a). Bacteria. Edinburgh : Livingstone.

Bisset, K. A. (1952b). Bacterial cytology. Int. Rev. Cytol. 1, 93.

BISSET, K. A. \& Moore, F. W. (1949). The relationship of certain branched bacterial genera. J. gen. Microbiol. 3, 387 .

Brieger, E. M. \& Robinow, C. F. (1947). Demonstration of chromatinic structures in avian tubercle bacilli in the early stages of development. J. Hyg., Camb. 45, 413. 
Cassel, W. A. (1951). A procedure for the simultaneous demonstration of the cell walls and chromatinic bodies of bacteria. J. Bact. 62, 239.

DeLamater, E. D. (1951 $a$ ). A staining and dehydrating procedure for the handling of microorganisms. Stain Tech. 26, 199.

Delamater, E. D. (1951b). A new cytological basis for bacterial genetics. Cold Spr. Harb. Sym. quant. Biol. 16, 381.

Delamater, E. D. (1952). Preliminary observation on the occurrence of a typical mitotic process in micrococci. Bull. Torrey bot. Cl. 79, 1.

Delamater, E. D. \& Hunter, M. E. (1951). Preliminary report of true mitosis in the vegetative cell of Bacillus megatherium. Amer. J. Bot. 38, 659 .

Delamater, E. D. \& Hunter, M. E. (1952). Observations on the nuclear cytology of spore germination in Bacillus megaterium. J. Bact. 63, 23.

DeLlamater, E. D. \& MUdD, S. (1951). The occurrence of mitosis in the vegetative phase of Bacillus megatherium. Exp. Cell Res. 2, 499.

KNAYSI, G. (1929). The cytology and microchemistry of Mycobacterium tuberculosis. J. infect. Dis. 45, 13.

KNaYsi, G. (1930). Cell structure and division of Bacillus subtilis. J. Bact. 19, 113.

Møller, V. \& Birch-Andersen, A. (1951). Some morphological changes caused by various treatments of bacteria, as studied by electron microscopy. Acta path. microbiol. scand. 29, 132.

Mudd, S., Brodie, A. F., Winterscheid, L. C., Hartman, P. E., Beutner, E. H. \& McLean, R. A. (1951). Further evidence of the existence of mitochondria in bacteria. J. Bact. 62, 729 .

Mudd, S., Winterscheid, L. C., Delamater, E. D. \& Henderson, H. J. (1951). Evidence suggesting that the granules of mycobacteria are mitochondria. J. Bact. 62, 459.

Murray, R. G. E. \& Robinow, C. F. (1952). A demonstration of the disposition of the cell wall of Bacillus cereus. J. Bact. 63, 298.

ReTtGer, L. F. \& Gillespie, H. B. (1935). Bacterial variation: an enquiry into the underlying principles governing the cell morphology of Bacillus megatherium. J. Bact. 30, 213.

Rosinow, C. F. (1945). Addendum to R. J. Dubos, The Bacterial Cell. Harvard: University Press.

\section{EXPLANATION OF PLATES}

Plate 1. Bacillus megaterium, $\times 3000$

Fig. 1. Cell walls stained by tannic acid violet. Bacilli typically have four cells, separated by cross-walls.

Figs. 2, 3. Lightly hydrolysed acid thionine, showing stainable elements in material lining cross-walls. The latter show as unstained gaps. Cell walls are also unstained.

Figs. 4, 5. Acid thionine, showing cross-walls and paired nuclear bodies.

Figs. 6, 7. Stainable elements in cross-walls demonstrated by haematoxylin.

Figs. 8, 9. Tannic acid violet preparations, dehydrated by DeLamater's method, showing shrinkage and distortion, for comparison with water-mounted preparations.

PI.Ate 2. Mycobacterium, $\times \mathbf{3 0 0 0}$

Fig. 10. M. lacticola, acid Giemsa, showing nuclear bodies and some cross-walls.

Figs. 11, 12. M. tuberculosis, cell walls and cross-walls by tannic acid violet. The organism is clearly multicellular.

Fig. 13. M. lacticola, tannic acid violet, showing cross-walls to occur even in very short elements. 
Journal of General Microbiology, Vol. 8, No. 1

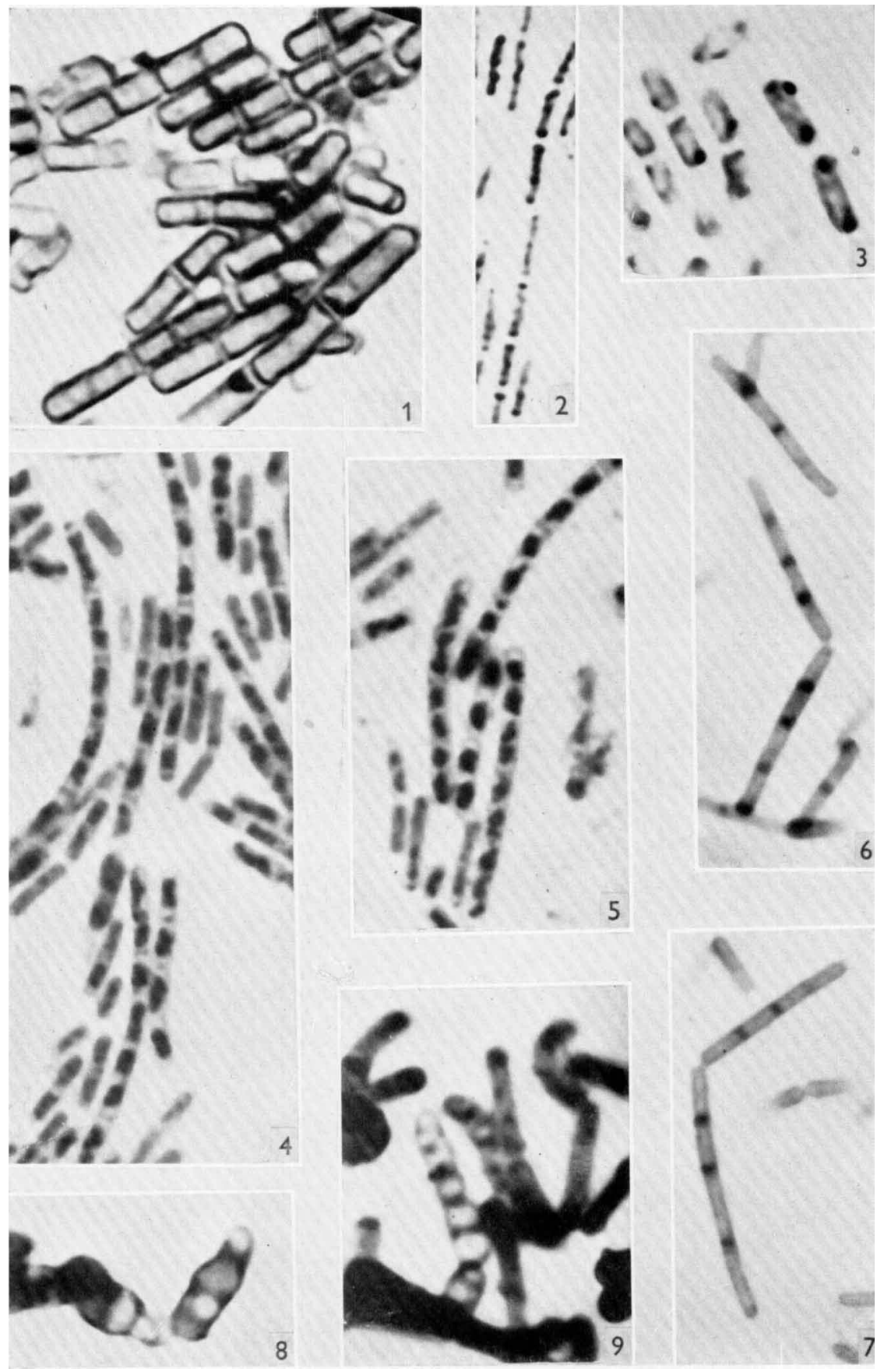

K. A. Bisset-Do bacteria mave mito'te spindles? Plate 1 
Journal of General Microbiology, Vol. 8, No. 1

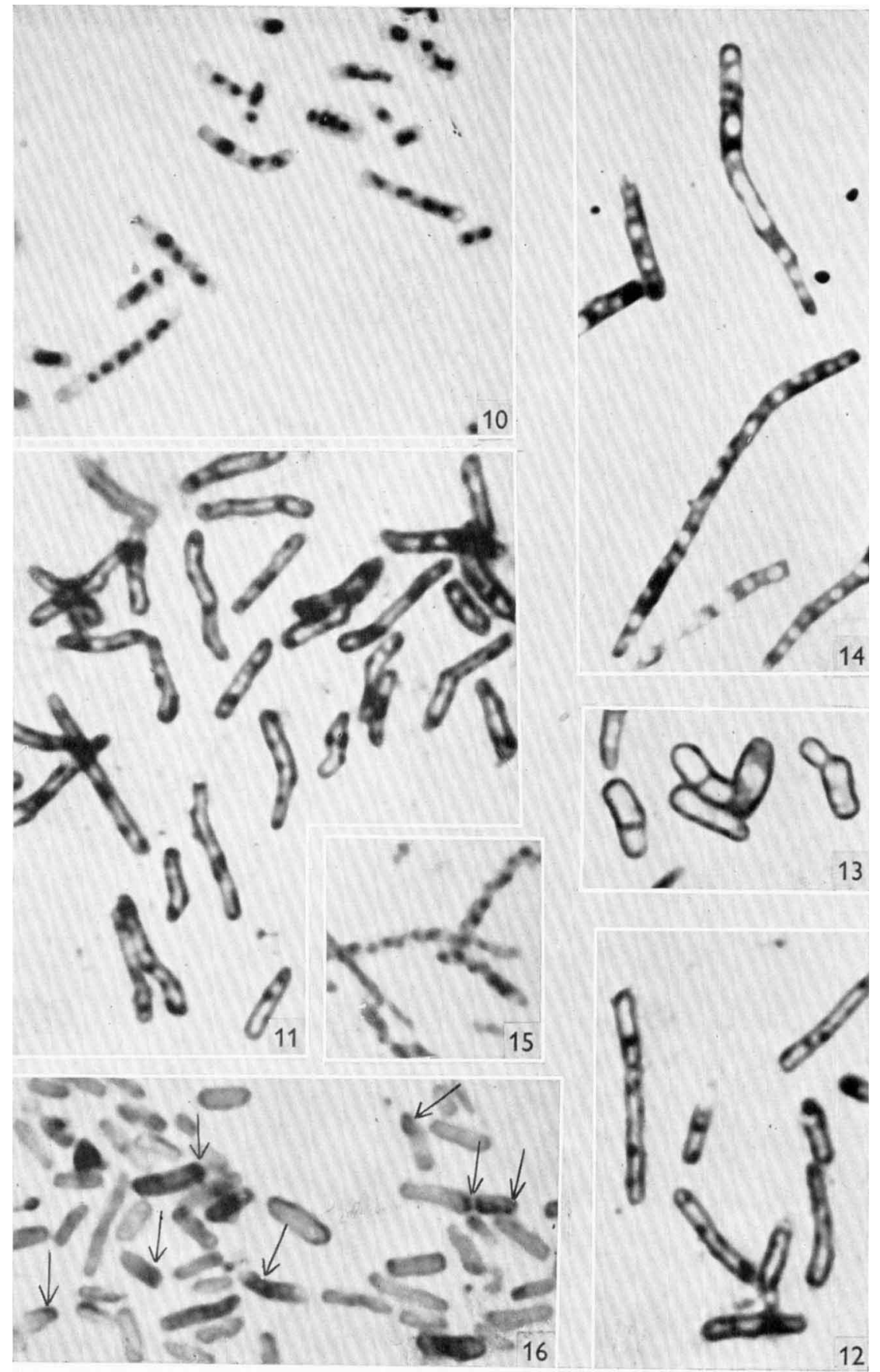

K. A. Bisset-Do bacthia have mitotic spindeles? Plate 2 
Journal of General Microbiology, Vol. 8, No. 1
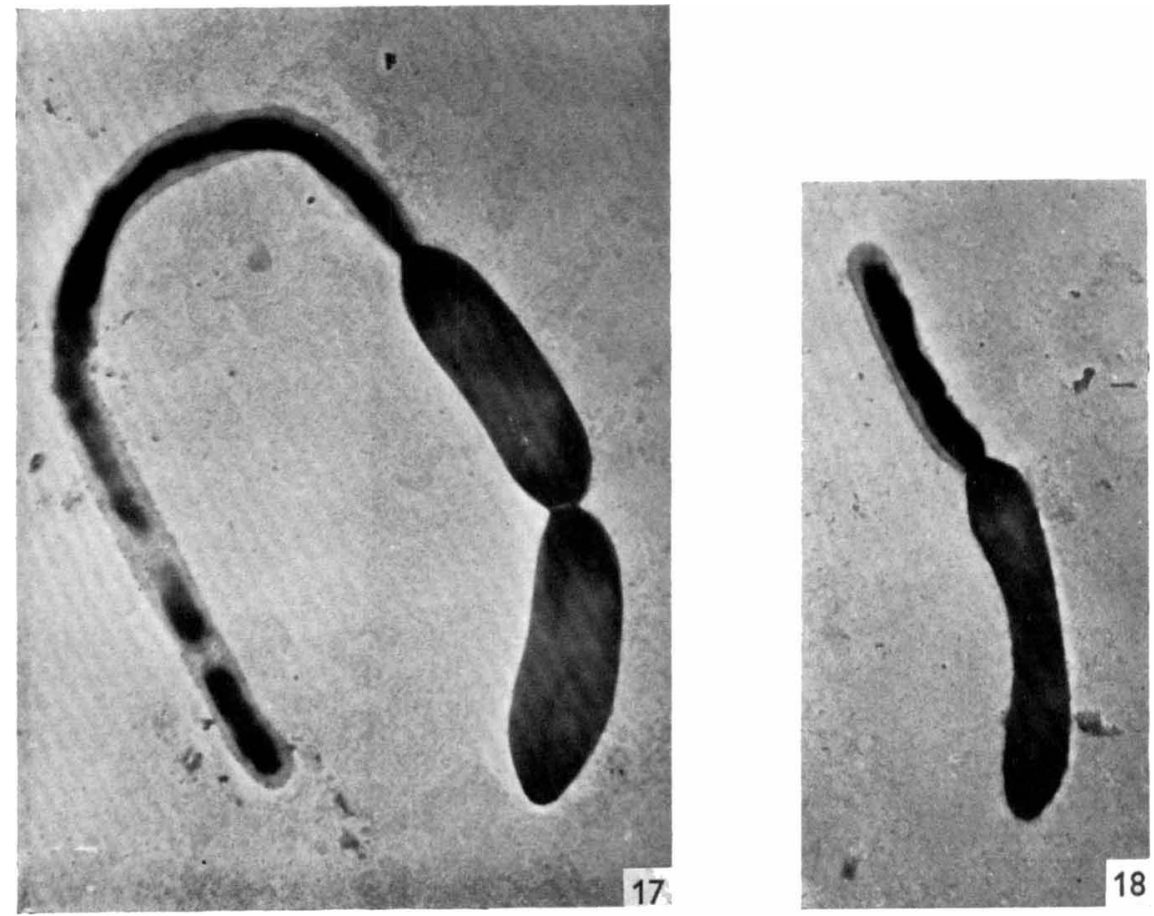

K. A. Bissef-Do bacteria have mitotic spindles? Plate 3 
Figs. 14, 15. Acid-fast organism from soil, tannic acid violet and acid Giemsa respectively. Multicellular, with thick cross-walls.

Fig. 16. Bacterium coli, $\times 3000$. Unhydrolysed, stained Giemsa. The stainable surfaces at the growing tips and points of division are seen.

\section{Plate 3}

Figs. 17, 18. Electron micrographs of $B$. megaterium, $\times 7000$, showing small, septate bacilli, in series with those of normal size. Appearances of this type are described by DeLamater as 'fusion tubes'.

(Received 11 June 1952) 